(TRJ) Tourism Research Journal

E-ISSN: 2598-9839

2020, Vol. 4 No. 1

\title{
Factors Influencing French Tourists to Visit Bali
}

\author{
Ferhadius Endi*, Danang Prasetyo
}

Sekolah Tingi Pariwisata Ambarrukmo (STIPRAM) Yogyakarta

*ferbadiusendi86@gmail.com

\begin{abstract}
This study discusses the factors that influence French tourists to visit Bali. This research is a qualitative descriptive study. The research data was obtained by observing, documenting and interviewing 48 French tourists who used the services of a travel agent during their vacation in Bali in 2019. To test the validity of the data, researchers used triangulation of techniques and sources. Then data analysis through the stages of data collection, data reduction, data display and drawing conclusions. Based on the results of research that has been conducted, it is found that there are 10 (ten) factors that influence French tourists to visit Bali; those are: (1) the beauty of the nature, (2) the hospitality of the Balinese people, (3) the rich history, local culture and traditions, (4) the competitive prices, (5) beaches and activities, (6) the traditional cuisine of Bali, (7) the convenience during vacation, (8) meditation and yoga facilities, (9) the availability of Francophone guide, and (10) the existence of Francophone community. The results of this study are expected to provide a strategic plan map for the development of tourism especially in Bali and in Indonesia in general.
\end{abstract}

Keywords: french tourists, Bali, tourism 


\section{A. Introduction}

The existence of Bali and tourism cannot be separated. As a major tourist destination in Indonesia, this island has main attractions that come from the wealth and the beauty of its nature, the uniqueness of its cultural arts (Somantri, 2019: 4). Bali, popularly known as the Island of the Gods, is the main and leading tourist destination in Indonesia. The image as a major tourist destination is further strengthened by the title of World's Best Destination by TripAdvisor which was released on March 7, 2018 (Christo, 2018).Unfortunately, in 2019, Tripadvisor placed Bali in the fifth place after London, Paris, Rome and Crete, Greek. The downgraded rating was partly due to the impact of the eruption of Mount Agung in the end of 2017 which affected the interest of foreign tourists to visit Bali as reported by printed and electronic media in Bali, as well as the impact of the European crisis that is still being felt until today (Dewi, 2017).

Based on data released by the Bali Provincial Tourism Office, the number of foreign tourists visited Bali in 2019 was 6,291,141. This number is expected to continue to increase to reach the target of 7,100,000 foreign tourists. Therefore various kinds of efforts are carried out by the government and the people of Bali in order to maximize tourism potential in Bali; for example, by building and developing infrastructure, creating new tourist spots and icons as well as increasing public participation in several sectors. The following is the data of the top 10 foreign tourists visited Bali from January to December 2019 based on the Bali Provincial Tourism Office data.

Table 1: Foreign Tourist Visitsto Bali in 2019

\begin{tabular}{lllll}
\hline Nationality & Rank & 2019 & $+/-(\%)$ & Share $(\%)$ \\
\hline Australian & I & 1.245 .410 & 6.52 & 19.80 \\
Chinese & II & 1.185 .519 & -12.93 & 18.84 \\
Indian & III & 374.784 & 5.90 & 5.96 \\
British & IV & 287.577 & 6.20 & 4.57 \\
American & V & 277.391 & 17.25 & 4.41 \\
Japanese & VI & 258.142 & -1.35 & 4.10 \\
South Korean & VII & 213.394 & 48.62 & 3.39 \\
French & VIII & 209.202 & 6.88 & 3.33 \\
German & IX & 197.691 & 6.36 & 3.14 \\
Malaysian & X & 185.279 & -4.87 & 2.95 \\
\hline
\end{tabular}

Source: Bali Provincial Tourism Office Statistics Data Release 2019.

The table shows the overall data of foreign tourists from various continents, but researchers only focus on tourists from the Europe, especially France. The researchers get thedata of European tourists visited Bali from the release ofthe Bali Provincial Tourism Office, then summarize the top 5 countries as presented in the table below. 
Table 2: European Tourist Visits to Bali in 2019:

\begin{tabular}{llll}
\hline Number & Country & Quantity & $\%$ \\
\hline 1. & United Kingdom & 287.577 & 4.57 \\
2. & France & 209.202 & 3.33 \\
3. & Germany & 197.691 & 3.14 \\
4. & Rusia & 143.357 & 2.28 \\
5. & Netherlands & 116.660 & 1.85 \\
\hline
\end{tabular}

Source: Bali Provincial Tourism Office Statistics Data Release 2019.

Based on the data table above, it can be seen that tourists from the UK, France and Germany occupy the top three positions for the most European tourists visiting Bali in 2019. The number of French tourists is 209.202 or 3.33\% of the total number of foreign tourists who came to Bali. In recent years the number of French tourists arrival has continued to increase. The authors summarized the data from the statistical data of the Bali Provincial Tourism Office in the following table which compares the numbers of French tourists visited Bali from 2014 to 2019.

Table 3: Data on Increasing French Tourist Visits to Bali

\begin{tabular}{cccccc}
\hline 2014 & 2015 & 2016 & 2017 & 2018 & 2019 \\
\hline 128.350 & 131.451 & 165.291 & 177.864 & 195.734 & 209.202 \\
\hline
\end{tabular}

The table above presents interesting information about the numbers of French tourists visitied Bali from 2014 to 2019. Interestingly, there is an increase in the number of French tourists visiting Bali from year to year. In France itself, Indonesia and VITO France (Visit Indonesia Tourism Officer France) have made efforts in order to increase the visit of French tourists to Bali, for example by the installation of Indonesian tourist billboards or posters at Charles de Gaule Airport and Paris Galeries Lafayette, broadcasting Bali and Indonesia tourist destinations in France Télévision and TV5 Monde, Indonesian participation in Salon du tourisme, short-term visa-free travel policy for French tourists, as well as other cultural activities aimed at introducing Bali and Indonesia more broadly to the French community.

The increasing number of French tourists to Bali is inseparable from the positive image of the island as"The Lost Paradise" which is getting stronger. Therefore, it is reasonable that Bali is on their vacation list, both with and without going through the services of a travel agent. For most French citizens, visiting Bali is a dream. This means that almost everyone hopes to visit Bali, but not a few of them are able to realize their dreams due to economic constraints, considerable distances and other factors.

This research discusses the factors that influence French tourists to visit Bali. The factors are both internal and external factors as a result of the positive 
perception of French tourists on the tourist destination of Bali or other reasons. As it is known that for French citizens, visiting Bali is not easy. The distance factor between France and Bali which is quite far away has an impact on the amount of their budget or travel costs and on the duration of the trip. However, based on the data in the table above, French tourists visits have increased from year to year. Therefore, this research is very interesting to do in order to find the deepest information about the factors that influence French tourists visiting and having vacation in Bali. The implications of this research are expected to make a positive contribution to the strategy of developing tourism in Bali in particular and in Indonesia in general.

\section{B. Literature Review}

Research on tourism in Bali is always interesting to do because of the complexity factor that is in line with the progress of tourism in Bali itself. One of the tourist attractions that also becomes a mainstay of Bali tourism is the local cultural tourism of Bali. Maritha (2010: 148) in her research stated that foreign tourists do not only focus on shopping tourism but also cultural tourism. Tri Hita Karana is one of the principles of local wisdom that is well preserved and widely known by not only the Balinese people but also the tourists. This principle teaches humans to try to maintain a harmonious relationship between humans and their God, between humans and humans and between humans and their environment, so that it can lead to happiness (Wijaya, 2015: 132).

Researches on tourist attractions on Bali itself have been carried out; one of them is by I Made Suradnyana (2005: 10). His research entitled "Analysis of the factors of tourist attraction in Bali and its implications for planning regional tourism in Bali" describes 8 factors which become tourist attractions for foreign tourists to tourist destinations in Bali; those are: (1) Prices of reasonable tourist products, (2) Culture in various forms of manifestations, (3) Beaches with all their attractions, (4) Leisure trips ( 5) Extensive opportunities for relaxation, (6) The image or big name of Bali, (7) Beauty of the Nature, and (8) The hospitality of Local People.

There are four interesting facts emerged in this research that are not found in I Made Suradnyana's research; those are: traditional Balinese food, meditation and yoga facilities, The existence of French-speaking guides, and the community of the French citizens or francophone community. Those facts show that tourism is dynamic. The changes are possible to happen because of the differences in time and tourist trends in Bali, as well as the differences in research objects.

The first difference is the emergence of French tourists' interest in Balinese culinary which is seen as the impact of expanding the definition of the tour itself. In addition, there is a shift in internet-based contemporary tourism trends that greatly support the development of the culinary tourism world. As an example, the rise of vloggers who make an assessment (review) on special cuisine of an area using you tube or instagram and other platforms seems to succeed in introducing 
an area through its special cuisine, and persuading tourists to travel to an area, completed with its special cuisine. A study conducted by Velyniawati, et al (2015: 64) stated that: 1) $66.7 \%$ said they really like the taste of traditional Balinese food; 2) $53.3 \%$ said they really like the color of traditional Balinese food; 3) 95\% stated that the portion of traditional Balinese food served was sufficient; and 4) 61.7\% level of foreign tourist acceptance of traditional Balinese food based on nutrients is good.

The second difference is that on the fifth point of research, I Made Suradnyana states the broad opportunity factor for relaxation. In this point, by visiting Bali, foreign tourists can relieve all fatigue or pressure due to the demands of work or their daily lives. The previous research discussed the importance of paying attention to carrying capacity as well as planning government policies that support and provide opportunities for foreign tourists to relax. However, the previous research did not specifically mention the intended forms of relaxation. In the world of tourism, there are various forms of efforts in the context of relaxation, for example: massage in the spa, sunbathing on the beach and the current trends of relaxation in Bali are meditation and yoga. This research specifically discusses the tourist attraction of Bali for French tourists because Bali is regarded as an ideal tourist destination for them which supports for meditation and yoga activities. Meditation is also very popular, especially for tourists who like spiritual experiences. This tour is intended for physical and spiritual cleansing which is termed as melukat which can be done at various sacred spring sources. Then, proceed with meditation activities to various sacred places that are usually provided by tour operators (Sukaatmadja, 2017: 536). Likewise, Tanah Lot is a sacred temple which is one of the centers of Hindu ritual activities, which has high resistance to tourism activities (Arifano, 2018: 7).

The third point that appears in this research but was not found in the research by I made Suradnyana is the existence of the French-speaking guides. According to Riani (2019: 11) the existence of a tour guide is very crucial during the tour who are at the forefront in providing services to tourists. Hendrawathy (2018: 18) explains the important role of a guide that talking or communicating is the main task for a guide. From the time of check-in at the airport, harbor, bus station, check-out (place of arrival and place of departure).

The fourth point that makes this research different to I made Suradnyana's is the existence of the francophone community. This point is important to be a common concern, especially for tourism actors in Bali. The presence of the community of French citizens must be seen as a positive indication of the attractiveness of Bali to the French community. The further analysis of this point will be discussed in the results and discussion section.

In addition to the four points of differences that have been described above, there are also several similarities factors found. Some of them are: the hospitality of the Balinese people, the beauty of the beach and its tourist attractions, and the convenience during holiday. 
The first point, I made Suradnyana in his research put the people factor which included the Balinese hospitality in the last position with a fairly low percentage of $3.6 \%$. Pendit (2002: 152) states that hospitality is considered a form of mutual respect, hospitality, and courtesy. In the tourism industry it is a spirit of tourism as well as providing sales value. Furthermore Martaleni (2011: 26) states that hospitality can be learned and given to the wider community in order to increase the empathy of officers and residents in serving tourists in a friendly and responsive manner to become a tourist community.

The second point, I Made Suradnyana explained that the tendency of tourists who like sea tourism is young tourists under 35 years old. All tourists recognize that Bali has quite a number of beautiful beaches. Like Sanur and Canggu Beach which has its own distinctiveness for foreign tourists in terms of tourist descriptors and trip descriptors (Tunjungsari, 2018: 120). It is supported by the emergence and development of tourists with special maritime interests. Ismayanti (2010: 40) mentions the term tourists as active sea lovers or active sea lovers, namely tourists who conduct marine tourism both on the beach and at sea. However, today, the problem of garbage on the beaches in Bali has become a serious concern of the community, tourists and the Regional Government of Bali. To overcome the waste problem, the government issued a Regional Regulation No. 3/2015. The purpose of the regulation was to improve the quality of the environment and also public health in Bali (Widyowati, 2018: 49).

The third point is the convenience during holiday. This factor discusses the convenience that arises because of security and satisfaction to the facilities and infrastructure that supports tourism. Facilities consisting of travel agents, tour operators, tourist transport, restaurants, accommodation, tourist attractions and infrastructure consisting of complementary facilities such as accessibility, restrooms, and security officers (Ghani, 2017: 30) .

This research discusses the tourist attraction of Bali for French tourists. Suwantoro (2004: 19) mentions tourist attraction as tourism object which is a potential support for tourists to attend and visit tourist destinations. Law No. 10 of 2009 defines a tourist destination as everything that has a uniqueness, beauty, and value in the form of diversity of natural wealth, culture, and man-made products of the destination of tourist visits.

The object of this research is French tourists who are part of foreign tourists. According to Kamus Besar Bahasa Indonesia, foreign tourists are tourists who come from abroad. Furthermore, Sunaryo (2013: 3) defines tourists as individuals or groups who take a tour with the purpose of recreation, business, or for other purposes, for example a special interest in something.

The research object of French tourists is choosen because the researchers saw the characteristics of French tourists that distinguish them from other foreign tourists (based on interviews with Salut Bali Tour and Travel). Characteristics of French tourists include: (1) preferring to stay in hotels that are authentic, natural and traditional Bali, (2) likes tourist attractions that are not so crowded and 
popular, (3) likes outdoor activities (trekking, camping, etc.), (4) likes typical restaurants with local Balinese menus, and (5) always include activities and interactions with local residents in each of their tour programs.

\section{Research Methodology}

This research is a qualitative descriptive study; researchers describe the data and the results of the research without involving quantitative data collection tools. The research was conducted in January 2019 until February 2020. The research locations are in several tourist objects in Bali.

For the data collection, researchers used observation, documentation and interview techniques. Then the data were analyzed qualitatively to test the validity of the data by triangulating techniques and sources. Data analysis through the stages of data collection, data reduction, data display, and drawing conclusions.

Data is taken from 48 French tourists who visited both for their first and for the umpteenth time in Bali. From 48 tourists, 15 tourists are those who have visited twice or more on holiday to Bali (repeaters), while 33 other tourists said that it was their first time to Bali. Interviews were conducted during and after their holidays. Respondents are French tourists who use the services of a travel agent during their vacation in Bali.

The reason for choosing French tourists who used the services of a travel agent is to specify the object of the research. The travel agent used for their services is Salut Bali Tour and Travel. Salut Bali Tour and Travel is a travel agent located in Yogyakarta with the main market is Francophone tourists (France, Switzerland and Belgium). The destinations offered are Bali, Java, Lombok, Sulawesi and Sumatra.

\section{Result and Discussion}

The tourist attractions in Bali seem to be endless; especially the nature and culture in Bali which are quite well preserved. The attraction of man-made tourism products is also growing rapidly following the world tourism trend; for example, Instagram-based tourism trends, such as the Lempuyang sublime temple, Ubud swing, and so on. This means that the destinations in Bali are very varied. Tourists can find both natural and man-made tourist destinations easily; furthermore, there are more and more choices of tourist destinations to visit. This becomes one of the reasons for French tourists to come and have a vacation to this 'thousand temples island'. Based on the data obtained, there are 10 points of tourist attractions in Bali for French tourists; those are:

\section{The Beauty of the Nature}

The first thing about Bali that almost all respondents agreed is that Bali is widely known for the beauty and diversity of its nature. The beauty and diversity of the nature is very well maintained by the cooperation of all parties. The people of Bali are very seriously working on the potential of their nature as tourist destination that is not only for the sake of economic motives, but there are other 
important elements. For them, the nature must be maintained and given high respect as in the concept of Tri Hita Karana. Tri means three elements, Hita means happy and Karana means cause. Therefore, Tri Hita Karana means three causes of happiness. This belief teaches human to try to maintain a harmonious relationship between human and their God, between human and human and between human and their environment; so that it can lead to happiness (Wijaya, 2015: 132).

French tourists express their high admiration for the nature in Bali. For them, the nature in Bali is so rich, seeing the green forest and rice fields supported by the ideal weather makes it comfortable to stay in Bali for a longer period. The combination of nature in Bali with everything that surrounds it provides inner peace for tourists; especially French tourists whose one of their reasons for vacation is for seeking peace. Therefore, it can be concluded that the beauty of the nature in Bali is not solely for visual satisfaction, but also for soul satisfaction and inner peace that is not found in their home country.

Some of natural tourists destinations in Bali that must be visited by French tourists are: (1) Jatiluwih, Tegalalang, and Belimbing as areas where there are terraced rice fields (rizière en terrasse) as their main destination. For French tourists, Bali's visual image is terraced rice fields. This is evident in several covers of tourist guide books (guides) and several Bali tourism advertisements; (2) Munduk, Bedugul, Ubud and Sidemen are four favorite destinations for French tourists for trekking activities, enjoying the beauty of lakes, forests and plantations as well as waterfalls. Those four areas are green areas which are still not too crowded of tourists (touristique), except Ubud. Even though Ubud City is already very crowded, for French tourists, the Ubud area remains enchanting and remains an idol. The beauty of the nature in Ubud is so captivating for the tourists; supported by the uniqueness of Ubud as the center of art in Bali; (3) Mount Agung and Mount Batur are the two most popular mountains in Bali for French tourists. Mount Agung which is the highest and sanctified mountain in Bali has always been a special attraction because its activities nowadays which are quite frequent and absorb a lot of world attention. However, the majority of respondents expressed no worry on the symptoms and natural disasters caused by Mount Agung. While Mount Batur is a combination destination where tourists can do trekking activities but also can enjoy the beautiful view of Lake Batur with the sunrise.

\section{The Hospitality of Balinese People}

Hospitality is one of the main elements and must exist in the world of tourism. The presence of the element of hospitality in the world of tourism is seen as a major component or spirit that enlivens all the services involved in it. Without hospitality, tourism is considered near death, lifeless and has no value to be sold. According to Pendit (2002: 152), he states that hospitality is considered a form of mutual respect and courtesy. In the tourism industry, it becomes the spirit of tourism as well as provides sales value.

For French tourists, one of the reasons they want to return to Bali is because of the typical Balinese hospitality that is rarely or even not found 
elsewhere. This hospitality seems quite difficult to describe but is very easy to feel. They stated that in general the hospitality of the Balinese is sincere hospitality, from the heart. The form of hospitality is very diverse, ranging from smiles when meeting and welcoming, serving with all the heart, high appreciation for the privacy and desires of guests, welcoming like at home, as well as making interactions that make tourists feel that they are in the circle of local Balinese community life. The impact is so great, ranging from creating a positive impression, a comfortable impression, a sense of trust, to becoming their reasons for returning to Bali.

The Balinese people have always been known as people who have a friendly nature. However, sometimes, a small problem happens in the field related to this hospitality. This might be happened due to the cultural difference between French tourists and local Balinese people. Therefore it is necessary to continuously provide professional hospitality understanding or even training for all parties involved in the tourism industry. Thus, the natural hospitality of the Balinese people is supported by the right knowledge and can then be applied appropriately. Therefore, misunderstandings arising from cultural differences can be minimized or even avoided. This can be done by increasing the empathy of officers and residents in serving tourists in a friendly and responsive manner. This can be done through providing education to officers and the surrounding community to become a tourist community (Martaleni, 2011: 26).

\section{The Wealth of History, Culture and Local Traditions}

History, culture and tradition are a unity of elements that make up the local wisdom of a community and region. Bali is so widely known by the world for its history, culture, and local traditions that are unique and alluring. The history of the kingdoms in Bali, the history of European colonization, the history of the existence of Hinduism in Bali, ancient stories, myths in Balinese society, as well as community traditions that are still well preserved and implemented are valuable tourist assets. It becomes an opportunity to increase the attractiveness for foreign tourists; moreover, based on research Maritha (2010: 148) foreign tourists do not only focus on shopping tourism but also on cultural tourism.

For French tourists, the people of Bali are known as people who are rich in history, culture and traditions; all of them are well preserved. The people love and are very proud of their local religion, culture and traditions, which in turn invite many tourists who want to know more about Bali, the Balinese people's behavior and their daily lives. One of the rituals in Bali is "Metatah" which is how the Balinese see the need for the ritual of filing canines in an effort to balance the elements in the body; the good and evil elements or commonly known as dharma and adharma.

Likewise, one of tourist destinations called Balai Kerthagosa, the building which was once a court of the Klungkung Kingdom, presents a historical story of the Kingdom of Karangasem and Klungkung with various symbols of resistance to colonialism. Starting from this site, French tourists see and recognize the 
tradition of making Wayang Kamasan, which has stories of ancient Balinese society found in the ceiling of the Great Hall and Bali Kerthagosa as a unique tradition for generations that are still well preserved. One of the stories in the wayang is the story of karmic forms which are believed by the Balinese Hindu community as a form of revenge in the hereafter. From these stories, French tourists began to understand the principles of Balinese life. As expressed by one of the tourists that the stories and information provided by the tour guide is very helpful for French tourists in understanding and exploring the principles and philosophies of Balinese life.

French tourists may feel incomplete if they do not have activities together with local residents. Many tourist villages offer tourists to do activities like local residents with the aim of introducing while providing life experiences; for example, the Tunjuk Tourism Village in Marga Village, Tabanan, which offers primary school visit activities in the village with the aim of introducing tourists to the educational process in Bali in particular and Indonesia in general. Furthermore, tourists will be invited to visit traditional markets that aims to introduce local Balinese products, learn to make Canang which is one of the basic needs of the Balinese Hindu community. There are also activities of learning to dance, playing music and learning Balinese script which become a compulsory art lesson for Balinese children. Moreover, those can be an effort to preserve customs and culture through the use of traditional clothing and Balinese language and script (Bali Provincial Tourism Office, 2019).

The activity continued with a walk through the village aimed at introducing the life system and layout of the village building, visiting the place of making palm sugar, making coffee, and visiting the temple which aims to introduce and provide opportunities for tourists to worship and pray like Hindu people in Bali. Activities in this tourist village will be ended by going down to the fields (plowing the fields and others) which aims to provide an experience to tourists how farmers process their fields. These activities can be found in other tourist villages with the theme of local wisdom of each region.

\section{The Competitive Tour Prices}

The provision of the tourism service industry cannot be separated from the promotion of prices offered by travel agents. Price is an important element that influences tourists coming to an area as a vacation destination. An attractive tourism service industry is not identical with cheap prices, but rather with the prices that are in line with the facilities and services that the tourists get.

The price of tour packages for French tourists is a private matter; French tourists never compare prices between one agent to another because the programs tend to be à la carte. This principle does not necessarily make tourism service providers arbitrarily make prices which aims to take as much profit as possible. Obviously, this act is against the rules, and French tourists tend to be critical in responding to any prices offered with the facilities provided. For French tourists, the prices offered by travel agents in Bali are very competitive; this is also 
influenced by the considerable market demand which is very beneficial for tourists because they can freely choose and determine their own type of vacation based on their budget.

Even though in 2019 the Regional Government of Bali has increased the tariff for entrance tickets for tours in Bali, the price and budget for a vacation for tourists is still relatively cheap compared to the prices for a vacation to other tourist destinations in other regions or countries; moreover, when it is compared to the prices in their home countries. As an illustration, the price of one serving of lunch in France ranges from 15 to 20 Euros or around 230,000 - 300,000 rupiah for 1 person. While in Bali, the price of one lunch portion is around 50,000 to 125,000 rupiah. In addition, hotel room rental prices in Ubud Bali per night for 3 star category hotels with deluxe room types range from 600.000 to 1.100 .000 rupiahs, while in Strasbourg France, the price of hotel rooms with the same room type is in the range of 1.000 .000 to 2.100 .000 rupiah. Therefore, it is important to be noted that even though there is a price gap between Bali and France; it does not means that tourism operators in Bali can raise the prices to be illogical. This will have a major impact on the sustainability of tourism in Bali itself, considering that French tourists are tourists who are active to criticize and very detailed to every penny of their budget.

\section{The Beauty of Beaches and Tourist Attractions}

The most popular tourist attraction for tourists is beaches. Like Sanur and Canggu Beach which have their own distinctiveness for foreign tourists in terms of tourist descriptors and trip descriptors (Tunjungsari, 2018: 120). Researchers found many assessments of the beauty of the beaches by French tourists who have special interests to come and enjoy the beaches and sea tourism. These tourists specifically come to Bali for the beaches and sea activities; although supported by cultural tourism activities. Ismayanti (2010: 40) mentions a specific term for this type of tourists as active sea lovers, the tourists who do marine tourism both on the beach and at sea. This type of tourist likes the challenges of the maritime world and likes to do new activities in the aquatic world, such as surfing, diving, sailing, and others. French tourists with this type generally spend more time at the beach or at sea. For example, from fourteen days of their vacation in Bali, they spend eight days on activities on the beach and at sea, such as surfing and snorkeling, then the other two days are for cultural visits, and the remaining four days are for free program.

Based on the results of this research, beaches in Bali which become the main destinations for French tourists are: (1) Amed and Tulamben which are two regions located in northeast Bali. Both areas are very popular for French tourists as a destination for underwater natural beauty with diving activities namely snorkeling and diving. Moreover, the tourists regard that the most interesting diving spot is in the Tulamben area with its main spot is the American battleship USAT Liberty which sank in World War II. Likewise, in Amed area, we can easily find an information board in French that offers learning services and rental of 
snorkeling and diving equipment. This indicates that many French tourists visit this area; (2) Seminyak and Uluwatu are two areas on the southern coast of Bali. Both of these areas are very popular with French tourists, one of the reasons is because they are often used as surfing spots. For beginner enthusiasts, Seminyak is considered an ideal spot because the waves are not too big and the beaches are not rocky; therefore, there is minimal risk of accidents. While the coast the Uluwatu area is devoted to professional surfers with all the challenges and risks.

Based on the analysis and explanation above, it is important for all parties to always maintain the sea and its attractions so that the sustainability of coastal tourism in Bali will continue. Responding to the rubbish problem that occurred on the coast of Bali lately, one of the respondents stated his willingness to return to Bali by bringing a project to clean the beaches in Bali and also continued the efforts to overcome the rubbish problem. This shows one of the characteristics of French tourists that is loyal to something they love and is also very sensitive to ecosystem problems and environmental cleanliness. In addition, the Environmental and Health Agency of Badung Regency stated that Bali is a rubbish emergency that includes well-known beaches such as Jimbaran, Kuta and Seminyak. To overcome the waste problem, the government issued Depansar City Regulation No. 3 of 2015. The purpose of the regulation was to improve the quality of the environment and public health in Bali (Widyowati, 2018: 49).

\section{The Traditional Balinese Cuisine}

Talking about food and cuisine today is not just about fulfilling the basic needs, but also about the collaboration of an art, culture, history and community of an area. As explained by the Food' n Road Team (2019) "Food tourism is composed of activities that provide experiences of consumption and appreciation of food and beverages, presented in such a way that value the history, the culture and the environment of a particular region".

The French country which has long been known as one of the world's culinary centers seems to have had a significant impact on the development of the culinary world in Bali. These influences come together with the presence of French citizens in Bali, both as tourists as connoisseurs as well as business owners of French café and restaurant in Bali. Researchers observed that the interest or demand for food tourism or food traveling is usually much in demand by tourists with special passion or hobbies related to food, as well as special jobs such as food vloggers or food reviewers, which emerged as a result of the flare and development of Instagram as a platform providing various photo and video-based information. Besides, this food travelling is also very interesting for tourists who have already been to Bali (repeaters; the reason is they want to get to know the traditions and life in Bali through food and to avoid repeating the same tourist destination visit as they have done before.

Traditional Balinese cuisines that have been repeatedly ordered by French tourists include: Balinese lawar, pepes ikan, sate lilit, banana pancakes, fried bananas with liquid palm sugar, fried rice, fried noodles, and lodeh sayur. These 
foods are known by French tourists in restaurants and hotels which are found in the breakfast menu and in the hotel restaurant. Some French tourists expressed their appreciation for Balinese cuisine. In their opinion, Balinese cuisine is created by the right combination of ingredients as well as the spices.

One of the respondents shared an interesting and unforgettable experience after attending a cooking class at a hotel. The activity aims to introduce and at the same time provide an opportunity for tourists to practice firsthand how the Balinese dishes they admire are made accompanied and guided directly by experienced chefs. The activity begins in the morning by shopping at traditional markets, accompanied by hotel staffs; tourists chose the ingredients to be cook. In addition to getting the desired ingredients, the program also introduces Balinese products and traditional life to French tourists. The results are very satisfying as evidenced by the response and reaction of tourists who are so enthusiastic. This impression is what they later bring to their country. That learning to cook food in Bali is not just about food processing, but also learning and diving into the lives of local Balinese people.

VITO France has even introduced Balinese and Indonesian traditional cuisines in France in order to bring Bali closer to the French people. In line with the efforts made by VITO France, the government through The Ministry of Tourism and Creative Economy plans to make the City of Ubud in Gianyar as the gastronomic capital of Indonesia. This means that this opportunity should be utilized as much as possible to further strengthen the image of Bali tourism through its cuisine.

The above explanation can strengthen the results of Tunjungsari's research (2018: 119) that foreign tourists prefer to enjoy food with local flavor. From 85 respondents, 58 respondents said they liked Balinese (local) food, 26 respondents said they liked western cuisine, and 1 respondent liked vegetarian. In addition there are results of research by Velyniawati, et al (2015: 64) that 1$)$ the majority of foreign tourists $(66.7 \%)$ said they really like the taste of traditional Balinese food; 2$)$ More than half of foreign tourists $(53.3 \%)$ said that they really like the color of traditional Balinese food; 3) Most foreign tourists (95\%) state that the portion of traditional Balinese food served is sufficient; and 4) Most (61.7\%) levels of foreign tourist acceptance of traditional Balinese food based on nutrients are good.

\section{The Convenience During Holiday}

All tourists crave for feeling convenience during their vacation. The feeling of comfort during a vacation is created by the collaboration of several elements. The convenience factor in this research addresses the elements of security and infrastructure in Bali. These two elements become the main discussion in this seventh point, considering that in the last few years, Bali has been so highlighted by the eyes of the world, especially because of these two elements.

According to respondents, even though Bali was plagued with issues and cases of terrorism in 2002 and 2005 which at that time destroyed the image of Bali tourism, but it no longer affected the interest of French tourists to visit Bali and 
even revisit it. One respondent believes that the issue and case of terrorism today is a global issue that can occur anywhere and at any time. They even gave examples of several acts of terrorism that once attacked the French state as happened in the Charlie Hebdo print media office in Paris on January 7, 2015, a truck that hit a crowd in commemoration of the French National Day on July 14, 2016 in the city of Nice, and also the attack terrorism in the Strasbourg City Christmas Market at the end of 2018.

Moreover, French tourists expressed their appreciation for the Police and the local government, who have seriously and readily monitored the flow of incoming and outgoing tourists, both local and foreign. One example is the checking of identity cards at Gilimanuk Port which aims to minimize the entry of terrorists through land and sea. Likewise, the issues and news related to the eruption of Mount Agung in recent years do not seem to affect the interest of tourists to come to Bali. It is not surprising that based on research by Tunjungsari (2018: 121), it is concluded that the perception of foreign tourists is that Bali is safe to visit and most tourists want to revisit it.

The second convenience factor arises because of the level of satisfaction of French tourists to infrastructure in general in Bali is quite high. For example, the good road conditions such as those found in Gilimanuk-Singaraja, GilimanukDenpasar, Denpasar-Ubud, Denpasar-Bedugul and others, a sufficient port with a sufficient number of ships, such as the Gilimanuk Port and Padangbai Port, the Bali Mandara toll road and also several underground lines (underpasses) that really help the smoothness of the trips and save time, especially trips to and from Denpasar Ngurahrai Airport.

Another term for infrastructure is all the fundamental facilitieswhich are elements that complement and aim to facilitate the process of tourism activities to run smoothly. Facilities consists of travel agents, tour operators, tourist transport, restaurants, accommodation (hotel / inn), attractions, tourist attractions and infrastructure consists of complementary facilities such as accessibility, restrooms, and security officers (Ghani, 2017: 30) .

\section{Meditation and Yoga facilities}

One of the points stated in a research conducted by Suradnyana is that the attractive tourist destination in Bali for foreign tourists is an opportunity for relaxation. In recent years, the demand for meditation tourism has increased quite sharply. The usual pattern is the number of tourists groups with a range of 10 to 15 participants in which there are meditation teachers. Researchers see a pattern of lifestyle changes in French society that occurred lately; they are actively participating in activities or tours in order to find inner peace or spiritual activities. This is caused by the high workload, the journey of life they have ever experienced. This makes the phenomenon of emptiness experienced by some French people in the last decade, as well as the need to train and increase concentration of mind and heart to support their career and work as expressed by one of the participants in the group meditation. 
For French tourists, Bali is an ideal destination to be able to combine several activities at once; for example, meditation or yoga accompanied by a visit of culture and nature. As stated by one of the meditation teachers from France that "l'ambiance, le climat, la gentillesse et le sourire, la tranquilite hamonieuse propice à notre travail" (atmosphere, climate, kindness and smiles, harmonious calm that is conducive to our work). Based on this opinion, one interesting conclusion can be drawn that Bali is an ideal destination for meditation and yoga. The condition was created by the collaboration of all elements that support one another to create an impression and a sense of convenience for tourists.

Meditation and yoga activities in Bali are supported by qualified and trained human resources and facilities. Several tourist destinations in Bali provide facilities for meditation and yoga classes, for example in the areas of Ubud, Sidemen, Munduk, and Tejakula. For French tourists, the group meditation participants assess these areas as a very suitable and ideal area for conducting meditation and yoga activities considering that these areas are very beautiful, calm and far from noise, and there are hotels that are accustomed to handling and welcoming guests with this special interest.

There is also an activity to heal illnesses or emotional woundsor known as healing, as well as other activities that aim to make participants feel young again by rearranging their body and soul better, known as rejuvenating. Both of these activities arose because of the need factor arising from the tourists themselves which was then responded positively by the tourism actors by utilizing and introducing traditional Balinese healing traditions. The involvement of experts or in this case is the hindu priest in the treatment attracts more the tourists to come. Meditation is also very popular, especially for tourists who like spiritual experiences. This tour is intended for physical and spiritual cleansing which is termed as melukat which can be done at various sacred spring sources. Then, proceed with meditation activities to various sacred places that are usually provided by tour operators (Sukaatmadja, 2017: 536). Likewise, Tanah Lot is a sacred temple which is one of the centers of Hindu ritual activities, which has high resistance to tourism activities (Arifano, 2018: 7).

\section{The existence of French Speaking Guides}

The existence of French-speaking guides, hereinafter referred to as francophone guides in the world of Bali tourism, adds a special attraction for Bali tourist destinations. According to Riani (2019: 11) the existence of a tour guide is very crucial in the visit of tourists who are at the forefront in providing services to tourists. Tour guides are the spearhead in the service to tourists, remembering from the mouth of guides, all information is conveyed to tourists. Hendrawathy (2018: 18) explains the important role of a guide by talking or communicating is the main task for a guide. From the time of check-in at the airport, harbor, bus station, check-out (place of arrival and place of departure) tour guides have started communication activities with tourists. Tour guides are one of the spearheads of 
tourism in Bali in transferring information about tourist destinations spread on Bali.

The presence of these guides is seen as a form of response to the many requests of French tourists for Francophone guides, bearing in mind that one of the distinctive characteristics of French tourists is that they prefer to use the services of French-speaking guides rather than English. This clearly shows an increase in the number of French tourists coming to Bali which is balanced by requests for French-speaking guides.

In Bali there are already many learning institutions or French courses. For example: Udayana University, Alliance Francaise, and other course institutions. In addition, not a few senior guides open training or private French learning courses. Even many local people who can speak French despite the usual grammatical abilities, but these shortcomings are covered by good guiding skills. This means that even though the information delivered in French is not yet grammatically correct, the essence of the information reaches tourists well. As expressed by one of the tourists that this is not a big problem as long as the essence of information does not change and arrives well to the tourists, and remains within the reasonable limits of the code of ethics.

Based on data from the Central Board of the Indonesian Tour Guide Association (DPP HPI) in Bali Province in 2020, there are 191 French-language guides that were officially licensed from the agency. From 191 guides, there are 166 men and 25 women. In addition, there are also many professions such as personal French-speaking driver-guide that are increasingly in demand by French tourists; of course, for the reason of economic budgeting for their holidays. Based on the exposure of French tourists, it would be nice if the francophone guide continued to practice the ability of French both verbally and non-verbally to get more appreciation from French tourists and add a positive image for tourism in Bali.

\section{Francophone Community}

Another important factor which becomes the reason for French tourists to take a vacation is the existence of a community of French citizens in Bali, both for the purposes of study, research, leisure and even business and investment. In addition, there are also French citizens who get married and live permanently in Bali. There is one French community in Bali with a Facebook platform with the name of "Bali Francophones" which has about 7400 members. The group is a platform for expatriates and French tourists to get information about everything about Bali in the context of the francophone (languages and others).

For French tourists, the presence of the group is considered quite helpful, especially to get solutions to the problems faced, as well as a medium to get information on hotels, restaurants and tourist attractions. In Bali, there are many hotels, villas, guesthouses and restaurants whose owners are French citizens; for example, the Villa Villa hotel located in Nusa Dua, the Balquisse Heritage Hotel 
in the Jimbaran area, and the Mathis Retreat Hotel in the Ubud area, Galanga Restaurant located in Amed, la Brasserie Restaurant in Jimbaran area, and others.

This community is always active with a variety of information about Bali, as well as information on the whereabouts of restaurants with the best French cuisine in Bali as a release of homesickness. According to Tripadvisor (2020) there are ten of the best French restaurants in Bali namely (1) St Tropez, (2) Blueseed, (3) Rev Bistro, (4) Odette Bali, (5) La Brasserie, (6) Ju-Ma- Na, (7) Mozaique Restaurant Gastronomique, (8) Folie Bali, (9) Café du M Monkey, (10) The Restaurant at The Legian Seminyak. The emergence of the businesses mentioned above seems reasonable considering that one of the basics of dynamic tourism and involving many people is the emergence and development of various business fields (Ismayanti, 2010: 1).

Furthermore, another impact arising from the existence of the Francophone community for French tourists is their increased confidence in Bali as a tourist destination. This is based on the perception of French tourists who consider that the presence of this community in an area becomes an indication, parameters and evidence that the area is suitable for the interests of the French community in general.

\section{E. Conclusion and Suggestions Conclusion}

In a research that discusses the factors that influence French tourists to visit Bali, several new interesting points were found; they are traditional Balinese food, meditation and yoga facilities, and the francophone community. This shows that tourism is dynamic following the development trend of human culture. In recent years, Bali as a major destination in Indonesia has attracted the attention of French tourists for a vacation. This is evidenced by the increasing number of French tourists to Bali from year to year. French tourists themselves are tourists who have special character traits that differentiate them from other foreign tourists, namely (1) prefer to stay at hotels with natural and traditional Balinese concepts, (2) prefer tourist attractions that are not so crowded and popular, (3) like activities in the wild (trekking, camping, etc.), (4) likes restaurants with local and Balinese specialties, and (5) likes activities and interactions with local residents. Based on the results of the research that has been conducted, there are ten factors that influence French tourists to go on holiday in Bali, namely: (1) the beauty of the nature, (2) the hospitality of Balinese people, (3) the rich history, local culture and traditions, (4) the competitive prices, (5) beaches and activities, (6) The traditional Balinese cuisine, (7) the convenience during holidays, (8) meditation and yoga facilities, (9) the availability of French-language guides (Francophone guides), and (10) the existence Francophone communities. By elaborating the results of this research, it is expected to be able to provide an even stronger map of strategic plans for the development of Bali and Indonesian tourism. 


\section{Suggestions}

Seeing the positive trend of French tourist visits from year to year, all tourism actors in Bali starting from the lowest to the top should be more sensitive and concerned about the great potential of French tourists. Such sensitivity and concern should have implications in efforts to attract more French tourists' hearts by an effort to always give a positive image of tourism in Bali before, during and after the holidays. It seems that promotions made by word of mouth are still considered as the most effective promotions. Maintaining the existence of Bali tourism in the future, the concept of Balinese natural development with Tri Karana concept which was designed by the predecessor of the predecessor is still relevant to maintain harmony and integrity of the nature of Bali comprehensively.

\section{REFERENCES}

Arifano, M.M. (2018). Tanah Lot Sebagai Daya Tarik Wisata di Bali. Domestic Case Study. Sekolah Tinggi Pariwasata Ambarrukmo Yogyakarta.

Christo, J.P. (7 Maret 2018).Bali named TripAdvisor`s Best Destination in the Worldhttps://en.tempo.co/read/916400/bali-named-tripadvisors-bestdestination-in-the-world.

Dewan Pimpinan Pusat Himpunan Pramuwisata Indonesia. (2020). Data Anggota Pramuwisata.

http://dpphpi.org/anggota\&dpd=b70efdf2ec9b086079795c442636b55fb c\&divisi $=245 \mathrm{c} 48 \mathrm{cce} 2 \mathrm{e} 2 \mathrm{~d} 7 \mathrm{fbdea} 1 \mathrm{afc} 51 \mathrm{c} 7 \mathrm{c} 6 \mathrm{ad} 26$ (retrieved on Janunary 27 , 2020 , at 16.00).

Dewi, S. (27 November 2017). Bandara Ngurah Rai Tutup Akibat Erupsi Gunung Agung Disorot Dunia. https://www.liputan6.com/global/read/3176629/bandara-ngurah-raitutup-akibat-erupsi-gunung-agung-disorot-dunia.

Dinas Pariwisata Provinsi Bali. (2019). Gaet Wisatawan Eropa, Pemprov Bali Genjot Pembangunan Infrastruktur dan Kebersiban Lingkungan. https:/ / disparda.baliprov.go.id/gaet-wisatawan-eropa-pemprov-baligenjot-pembangunan-infrastruktur-dan-kebersihan-lingkungan/.

Dinas Pariwisata Provinsi Bali. (2019). Rilis Data Statistik Sementara Desember 2019. https://disparda.baliprov.go.id/rilis-data-statistik-sementara-desember2019/.

Food'n Road Team. (2019).What is Food Travel. https:// foodandroad.com/foodtravel/ (retrieved on January 28, 2020, at 22.25).

Ghani, Y.A. (2017). Pengembangan Sarana Prasarana Destinasi Pariwisata Berbasis Budaya di Jawa Barat. Jurnal Pariwisata, Vol. IV No. 1 April 2017, hal 22-31. 
Hendrawathy, I.D.A. (2018) Strategi Komunikasi Pramuwisata dalam Menjaga Eksistensi Pariwisata Bali. Jurnal Pariwisata Budaya, Vol.3 Nomer 1, Tahun 2018, hal 1-19.

https://bali.tribunnews.com/2019/12/29/asita-bali-target-wisatawan-ke-balitahun-2020-sebanyak-7-juta-wisatawan-harus-say-no-to-plastic (retrieved on January 30, 2020, at 05.55).

Ismayanti. (2010). Pengantar Pariwisata. Jakarta: Grasindo.

Maritha, D.P. (2010). Profil Pola Pengeluaran Wisatawan Asing Ala Backpacker di Yogyakarta. Skripsi. Fakultas ekonomi, Universitas Sebelas Maret Surakarta.

Martaleni. (2011). Pertumbuhan Pariwisata Global: Tantangan Untuk Pemasaran Daerah Tujuan Wisata (DTW). Jumal Manajemen Teori dan Terapan, Tahun 4, No. 2, Agustus 2011, hal 18-27.

Pendit, Nyoman S. (2002). Ilmu Parwisata: Sebuah Pengantar Perdana. Jakarta: Pradnya Paramita.

Riani, N.K. (2019). Peranan Seorang Guide dalam Dunia Pariwisata.http://103.43.45.136/siki/assets/dokumen/Karya_Tulis_29_V 1_595c49389916c.pdf.

Somantri, L. (2019). Keunggulan Bali sebagai Daerah Tujuan Wisata Andalan Indonesia.http:/ / file.upi.edu/Direktori/FPIPS/JUR._PEND._GEOGR AFI/132314541-LILI_SOMANTRI/makalah_bali.pdf.

Sukaatmadja, I.P.G, dkk. (2017). Pariwisata Spiritual : Berbasis Event-Event Upacara Agama Hindu. Prosiding Seminar Nasional AIMI, Jambi, 27 - 28 Oktober 2017, hal 529-538.

Sunaryo, B. (2013).Kebijakan Pengembangan Destinasi Pariwisata, Konsep dan Aplikasinya di Indonesia. Yogyakarta:Gava Media.

Suradnya, I.M. (2005). Analisis Faktor-Faktor Daya Tarik Wisata Bali dan Implikasinya Terbadap Perencanaan Pariwisata Daerah Bali.https://media.neliti.com/media/publications/43993-ID-analisisfaktor-faktor-daya-tarik-wisata-bali-dan-implikasinya-terhadapperencan.pdf (retrieved on January 26, 2020, at 18.30).

Suwantoro, G. (2004). Dasar-Dasar Pariwisata. Yogyakarta: Penerbit ANDI.

Tripadvisor. (2020). French in Bali.https://www.tripadvisor.com/Restaurants-g294226-c20-Bali.html (retrieved on January 29, 2020, at 10.20).

Tunjungsari, K.R. (2018). Karakteristik dan Persepsi Wisatawan Mancanegara di Kawasan Sanur dan Canggu, Bali. Jurnal Pariwisata Terapan, No. 2, Vol. 2, 2018, hal 108-121. DOI: https://doi.org/10.22146/jpt.43178.

Undang-Undang No.10 Tahun 2009 Tentang Kepariwisataan.

Velyniawati, dkk. (2015). Tingkat Penerimaan Wisatawan Asing Terhadap Makanan Tradisional Bali. Jurnal Ilmu Giri, Volume 6 Nomor 1 Februari 2015: $58-65$. 
Widyowati, W, dkk. (2018). Kebijakan Pemerintah Kota Denpasar Terhadap Upaya Pencegahan Pencemaran Lingkungan Hidup di Kota Denpasar.Jurnal Reformasi Hukum: Cogito Ergo Sum, Volume 1, Nomor 2, Juli 2018, 45-50.

Wijaya, K. (2015). Masa Depan Pariwisata Bali (Perspektif Permasalahan dan Solisinya. Journal of Research in Economics and Management. Volume 15, No. 1, Januari - Juni (Semester I) 2015, Halaman 118-135. 